\title{
PEMANFAATAN LIDAH MERTUA SEBAGAI HAIR TONIC UNTUK PERAWATAN RAMBUT RONTOK
}

\author{
Aprilia ${ }^{1}$, Hayatunnufus, ${ }^{2}$ \\ ${ }^{1}$ Jurusan Tata Rias dan Kecantikan, Fakultas Pariwisata dan Perhotelan, Universitas Negeri Padang \\ ${ }^{2}$ Program Studi Pendidikan Tata Rias dan Kecantikan, Fakultas Pariwisata dan Perhotelan, Universitas Negeri Padang \\ e-mail: aprilia.p.13041996@gmail.com
}

\begin{abstract}
Abstrak
Rambut dikatakan rontok jika mencapai 50-100 helai dalam sehari.Tujuan penelitian untuk menganalisis pemanfaatan lidah mertua sebagai hair tonic untuk perawatan rambut rontok. Penelitian ini adalah eksperimen semu (quasi exsperiment) dengan desain Non equivalent control group design. Dengan populasi wanita yang berusia 19-25 tahun yang menggunakan hijab. Teknik pengambilan sampel menggunakan teknik purposive sampling dilakukan secara volunter sebanyak 9 orang. Sampel dalam penelitian ini dibagi menjadi tiga kelompok.Kemudian dilakukan uji normalitas, uji homogenitas dan uji analisis varians (ANAVA) dan dilanjutkan dengan uji duncan.Hasil analisis menunjukkan bahwat kelompok kontrol (X1) dengan nilai rata - rata 2,33 (pretest) menjadi 2,73 (posttest). Kelompok eksperimen 1 frekuensi 1 kali 2 hari (X2) mengalami perubahan dengan rata-rata 2,00 (pretest) menjadi 3,33 (posttest). Kelompok eksperimen 2 frekuensi 1 kali 3 hari (X3) juga mengalami perubahan dengan rata-rata 2,00 (pretest) menjadi 3,07 (posttest). Perhitungan rata - rata ketiga kelompok perlakuan dinyatakan bahwa Fhitung > Ftabel $(5.810>1.860)$ yang berarti terdapat perbedaan yang signifikan.
\end{abstract}

Kata kunci: Rambut Rontok, Hair Tonic, Lidah Mertua

\begin{abstract}
Hair is said to fall out if it reaches 50-100 strands. This research aims to analyze the use of senseviera as hair tonic for the treatment of hair loss .This research is a quasi-experiment with the design of Non Equivalent Control Group Design. The population is women aged 1925 years who use hijab. The sampling technique was carried out by purposive sampling technique conducted voluntarily as many as 9 people. After obtaining the data, the normality test, homogeneity test and variance analysis test (ANAVA) were first carried out and continued with the duncan test. The results of the analysis showed that there was no change in the control group (X1) with an average value of 2.33 (pretest) to 2.73 (posttest). For the experimental group 1 frequency of 2 times a day (X2) since the first treatment (pretest) can be seen changes with an average of 2.00 (pretest) to 3,33 (posttest). Whereas in the experimental group 2 frequency 1 time 3 days (X3) also changed since and get an average of 2.00 (pretest) to 3.07 (posttest). The average calculation of the three treatment groups stated that Fcount> Ftable $(\mathbf{5 , 8 1 0}>1,860)$, which means that there was a significant.
\end{abstract}

Keywords: hair loss, hair tonic, senseviera 


\section{JPK}

\section{PENDAHULUAN}

Indonesia merupakan salah satu negara yang memiliki iklim tropis. Iklim tropis di Indonesia menyebabkan cuaca panas yang bisa menimbulkan beberapa masalah pada kesehatan rambut dan kulit kepala, seperti terkena sinar matahari yang dapat membuat rambut menjadi kering, rapuh, dan mudah rontok. Negara Indonesia juga terkenal dengan tingkat polusi yang sangat tinggi terutama dikota-kota besar, pencemaran ini disebabkan oleh banyaknya kendaraan bermotor yang mengeluarkan asap pembakaran, dengan adanya pencemaran udara ini dapat mengakibatkan rambut dan kulit kepala menjadi lemah dan berkemungkinan munculnya gangguan pada kulit kepala dan kerontokan yang dapat dialami oleh wanita maupun pria.

Rambut dikatakan mengalami kerontokan pada tahap yang mengkawatirkan apabila rambut terlepas dari kulit kepala mencapai 50-100 helai setiap harinya (Sani, 2010). Pernyataan serupa juga disampaikan oleh Tranggono (2007:36) bahwa "Rambut rontok merupakan hal yang wajar terjadi pada manusia selama rambut rontok yang terjadi berkisar 40-100 helai setiap harinya". Rambut kepala yang panjang akan lebih banyak rontoknya dibandingkan dengan rambut kepala yang pendek dikarenakan rambut yang panjang lebih berat hingga mengakibatkan tarikan pada rambut yang berlebihan.

Jelas dalam hal ini bahwa rambut rontok akan mudah dialami bagi orang yang menderita beberapa penyebab di atas. Dengan demikian rambut dikatakan rontok apabila terlepas dari kulit kepala dengan jumlah mencapai lebih dari 50-100 helai setiap harinya. Rambut mengalami kerontokan dikarenakan oleh beberapa faktor. Terkait hal di atas Rostamailis \& Hayatunnufus (2008:45) menyatakan "Penyebab rambut rontok antara lain dikarenakan stress, terlalu banyak mengkonsumsi obat-obatan, ketidak seimbangan hormon, menopouse, pemakaian zat kimia yang berlebihan pada kulit kepala dan rambut, ketombe, shampoo, sering mencatok rambut, sering menggunakan hair drayer, dan sebagainya".

Rahmadewi (2012:3) menambahkan bahwa: “ Faktor kerontokan dikarenakan oleh lingkungan dan polusi serta kadar air pada rambut, serta bahan perawatan rambut seperti shampoo, obat pengeriting, pelurus rambut, pewarna, pemudar rambut serta model tatanan rambut. Rambut rontok akibat faktor di atas dapat terjadi melalui mekanisme patahnya batang rambut, kerontokan dan kebotakan".
Dari pendapat di atas dapat disimpulkan bahwa rambut rontok akan mudah dialami dikarenakan oleh faktor polusi, pola hidup, cara merawat rambut dan juga diakibatkan oleh kekurangan vitamin yang dapat mencegah kerontokan dan mempertahankan kekuatan rambut. Untuk itu agar tidak terjadi hal yang tidak diinginkan maka dapat dilakukan pencegahan dini dengan melakukan perawatan sehari-hari.

Berkaitan dengan hal tersebut, Perawatan rambut yang sesuai dan teratur sangat diperlukan untuk mendapatkan rambut yang bersih dan sehat karena dengan melakukan perawatan rambut dapat membantu mengatasi permasalahan yang ditimbulkan oleh faktorfaktor penyebab masalah kesehatan rambut, dalam upaya perawatan rambut rontok baik pria maupun wanita dapat dilakukan dengan perawatan dari dalam dan dari luar.

Menurut Rostamailis \& Hayatunnufus (2008:161): "Perawatan dari dalam dengan cara mempertahankan gizi yang seimbang dalam kehidupan sehari-hari seperti memakan buah-buahan dan sayur-sayuran yang mampu menjaga kesehatan rambut, sedangkan untuk perawatan dari luar yaitu dengan cara perawatan rambut dengan sebaik-baiknya di salon dan juga bisa menggunakan bahan alami”.

Dalam melakukan perawatan rambut rontok harus menggunakan kosmetik untuk perawatan khusus rambut rontok. Namun, penggunaan kosmetik kimiawi sering menimbulkan permasalahan pada manusia.Hasil penelitian Nurjanah\& Krisnawati (2014:2) "Zat kimia yang terkandung didalam kosmetika untuk mengatasi rambut rontok memungkinkan timbulnya efek samping seperti alergi kulit, sakit kepala, vertigo, sampai penurunan tekanan darah". Reaksi negatif penggunaan kosmetika berbahan kimia ini dapat membahayakan bagi pengguna kosmetika, sehingga sebagai alternatif penggunaan kosmetika tersebut dapat digantikan dengan bahan kosmetika alami yang memiliki kandungan yang serupa dengan bahan kosmetika pabrik agar memiliki manfaat yang sama.

Bahan-bahan alami yang memiliki fungsi menyuburkan rambut dan mencegah kerontokan rambut sangat banyak ditemui seperti daun seledri, lidah buaya, lidah mertua dan masih banyak lagi yang dapat dimanfaatkan, dengan berbagai macam bahan alami yang dapat digunakan sebagai penyubur rambut yang dibuat menjadi bahan kosmetik seperti hair tonic yang dapat digunakan pada kulit kepada sebagai kosmetik penumbuh rambut.

Pada prinsipnya kosmetik terkelompok kepada beberapa jenis, seperti dikemukakan oleh Rostamailis (2005:16-18) yaitu “(1)Kosmetik tradisional (2) kosmetik semi tradisional, (3) kosmetik modern”. 
Tranggono (1992:30) menyatakan bahwa "Pemakaian kosmetika tradisional bisa digunakan satu kali dalam dua hari dan satu kali dalam tiga hari”.

Penggunaan hair tonic sebagai perawatan rambut rontok dianggap cukup efisien karena dapat dilakukan dirumah dan pemakaiannya sangat mudah. Menurut Nurjanah\& Krisnawati (2014:2): “ Formula hair tonic terdiri atas bahan alami berasal dari tumbuhan-tumbuhan yang digunakan untuk bahan pembuatan hair tonic. Bahan-bahan alami seperti yang ada pada lidah mertua mengandung abamageum yang berkasiat untuk penyubur rambut".

Lidah mertua merupakan tanaman yang mengandung flavonoid, asam galat dan vitamin C berkasiat untuk mengobati diabetes (Annisa, 2012). Sesuai dengan Hariana dalam Nurjannah \& Krisnawati (2014:8) menyatakan bahwa, "Bahan daun lidah mengandung vitamin $\mathrm{C}$ yang di dalamnya terdapat kandungan berfungsi untuk pertumbuhan rambut dan menyuburkan rambut, kandungan senyawa seperti flavonoid, saponin, tanin, polifenol dan alkaloid berfungsi sebagai zat antioksidan alami”. Polifenol ialah turunan fenol yang memiliki aktivitas sebagai antioksidan. Senyawa phenolic berfungsi dalam menyerap dan menetralkan radikal bebas atau menguraikan peroksida. Antioksidan fenol sebagai pencegah kerusakan akibat reaksi oksidasi (Osawa, 1994:241).

Sedangkan flavonoid merupakan golongan terbesar dari fenol yang memiliki sifat efektif dalam menghambat pertumbuhan bakteri dengan cara inaktivasi protein. Fenol bersifat lipofilik yang akan merusak membran mikroba, memiliki kemampuan untuk mendenaturasi protein dan merusak membran sel tanpa dapat diperbaiki (Rinawati, 2010:25). Rostamailis \& Hayatunnufus (2008:16) menambahkan, “ Tanaman lidah mertua sangat berguna sebagai penyubur rambut terutama untuk rambut yang sudah mengalami kekeringan dan rambut pecahpecah dengan cara mengoleskan langsung perasan lidah mertua kekulit kepala".

Berdasarkan penjelasan yang telah dijelaskan di atas penulis bermaksud menggunakan hair tonic alami dari daun lidah mertua sebagai bahan hair tonic yang akan penulis gunakan untuk perawatan rambut rontok pada mahasiswa Universitas Negeri Padang (UNP). Berdasarkan observasi dan wawancara yang telah penulis lakukan pada 5-10 februari 2018 terhadap masyarakat khususnya mahasiswa Universitas Negeri Padang (UNP) yang rata-rata berusia 19-25 tahun, di temui fakta bahwa sebagian mahasiswi mengeluhkan setiap bangun tidur adanya rambut rontok yang tertinggal di bantal dan juga ada yang mengeluhkan setiap menyisir rambut serta pada hijab yang digunakan selalu ada rambut yang rontok dalam jumlah banyak.

Berdasarkan latar belakang dan pengamatan penulis, menunjukkan bahwa banyaknya permasalahan rambut rontok yang dialami oleh mahasiswa Universitas Negeri Padang (UNP) yang berusia 19-25 tahun. Oleh karena itu penulis tertarik melakukan penelitian pada lidah mertua yang digunakan sebagai Hair Tonic pada rambut rontok, karena lidah mertua mengandung flavonoid, saponin, polifenol serta vitamin $\mathrm{C}$ yang dapat mempercepat pertumbuhan rambut, dengan judul "Pemanfaatan Lidah Mertua Sebagai Hair Tonic Untuk Perawatan Rambut Rontok".

\section{METODE}

Metode penelitian ini menggunakan metode eksperimen semu (quasi exsperiment). Penelitian dilakukan dalam desain Non equivalent control group design. Sampel pada penelitian ini dibagi menjadi tiga kelompok, yaitu kelompok kontrol dengan simbol (X1), kelompok eksperimen 1 dengan simbol (X2), kelompok eksperimen 2 dengan simbol (X3). Teknik pengambilan sampel dilakukan dengan teknik purposive sampling yaitu teknik pemilihan sekelompok subjek didasarkan atas ciri-ciri tertentu yang erat dengan ciri-ciri populasi yang sudah diketahui sebelumnya. Sampel dalam penelitian ini adalah sebagian dari sekelompok orang yang memiliki kerontokan rambut dengan jumlah sampel 9 orang merupakan wanita berumur 19-25 tahun dilingkungan dekat penulis yang mengalami kerontokan akibat kosmetik, penataan rambut serta penggunaan jilbab sendiri. Sampel yang diambil harus homogen, maksudnya keadaan awal sampel dengan gejala terhadap pengaruh kerontokan rambut yang dirasakan selama perlakuan, seperti tidak boleh menggunakan obat atau kosmetik perawatan rambut rontok lain untuk merawat rambut rontok. Tempat dan waktu penelitian dilakukan di Workshop Program Studi Pendidikan Tata Rias dan Kecantikan, Fakultas Pariwisata dan Perhotelan, Universitas Negeri Padang. Teknik analisis data dilakukan dengan menggunakan. Uji analisis varians (ANAVA) dan dilanjutkan dengan uji duncan.

\section{HASIL DAN PEMBAHASAN}

A. Hasil Penelitian

1. Deskripsi Hasil Penelitian Perawatan Rambut Rontok Tanpa Pemanfaatan Lidah Mertua Sebagai Hair TonicPada Kelompok Kontrol (X1) 
Tabel 1. Skor Tingkat Keberhasilan dalam

Perawatan Rambut Rontok pada Kelompok Kontrol (X1)

\begin{tabular}{|c|c|c|c|c|c|c|c|}
\hline \multirow{2}{*}{ sampel } & \multicolumn{7}{|c|}{ hasil observasi } \\
\cline { 2 - 8 } & Pretest & p1 & p2 & p3 & p4 & p5 & p6 \\
\hline 1 & 2 & 2 & 3 & 3 & 3 & 3 & 3 \\
\hline 2 & 3 & 2 & 3 & 3 & 3 & 3 & 3 \\
\hline 3 & 2 & 3 & 3 & 3 & 3 & 3 & 2 \\
\hline Jumlah & 7 & 7 & 9 & 9 & 9 & 9 & 8 \\
\hline $\begin{array}{c}\text { rata- } \\
\text { rata }\end{array}$ & 2,3 & 2,3 & 3 & 3 & 3 & 3 & 2,7 \\
\hline
\end{tabular}

Berdasarkan Tabel 1 di atas dapat diuraikan bahwa penilaian perawatan rambut rontok tanpa penggunaan lidah mertua sebagai hair tonic sebagai perawatan rambut rontok yaitu kerontokan rambut secara rata-rata menunjukkan skor 2,3 pada saat pretest, perlakuan 1 ratarata skor 2,3, perlakuan 2,3,4 dan 5 menunjukkan ratarata 3 sedangkan pada perlakuan 6 menunjukkan rata-rata 2,7 .

2. Deskripsi Hasil Penelitian Perawatan Rambut Rontok MenggunakanLidah Mertua Sebagai Hair TonicPada Kelompok Eksperimen 1 (X2)

Tabel 2. Skor Tingkat Keberhasilan dalam Perawatan Rambut Rontok pada Kelompok Eksperimen 1, Frekuensi 1 Kali 2 Hari (X2)

\begin{tabular}{|c|c|c|c|c|c|c|c|}
\hline \multirow{2}{*}{ sampel } & \multicolumn{7}{|c|}{ hasil observasi } \\
\cline { 2 - 8 } & Pretest & p1 & p2 & p3 & p4 & p5 & p6 \\
\hline 1 & 2 & 2 & 3 & 3 & 4 & 4 & 4 \\
\hline 2 & 2 & 3 & 3 & 3 & 4 & 4 & 4 \\
\hline 3 & 2 & 2 & 3 & 3 & 3 & 4 & 4 \\
\hline jumlah & 6 & 7 & 9 & 9 & 11 & 12 & 12 \\
\hline $\begin{array}{c}\text { rata- } \\
\text { rata }\end{array}$ & 2 & 2,3 & 3 & 3 & 3,6 & 4 & 4 \\
\hline
\end{tabular}

Berdasarkan tabel 2 di atas dapat diuraikan bahwa penilaian perawatan rambut rontok menggunakan lidah mertua sebagai hair tonic dengan frekuensi 1 kali 2 hari yaitu jumlah rambut yang rontok dari kepala secara ratarata menunjukkan skor 2 , pada perlakuan 1skor rata-rata 2,3, pada perlakuan 2 dan 3 skor rata-rata 3 , pada perlakuan 4 skor rata-rata 3,6, dan pada perlakuan 5 dan 6 skor rata-rata 4. Hasil penelitian ini menunjukkan tingkat keberhasilan perawatan rambut rontok menggunakan lidah mertua sebagai hair tonic menunjukkan keberhasilan dari saat pretest sampai perlakuan 6 .
3. Deskripsi Hasil Penelitian Perawatan Rambut Rontok MenggunakanLidah Mertua Sebagai Hair TonicPada Kelompok Eksperimen 2 (X3)

Tabel 3. Skor Tingkat Keberhasilan dalam Perawatan Rambut Rontok pada Kelompok

Eksperimen 2, Frekuensi 1 Kali 3 Hari (X3)

\begin{tabular}{|c|c|c|c|c|c|c|c|}
\hline & \multicolumn{7}{|c|}{ hasil observasi } \\
\cline { 2 - 9 } sampel & Pretest & p1 & p2 & p3 & p4 & p5 & p6 \\
\hline 1 & 2 & 2 & 3 & 3 & 3 & 4 & 4 \\
\hline 2 & 2 & 3 & 3 & 3 & 3 & 4 & 4 \\
\hline 3 & 2 & 2 & 2 & 3 & 3 & 3 & 3 \\
\hline Jumlah & 6 & 7 & 8 & 9 & 9 & 11 & 11 \\
\hline $\begin{array}{c}\text { rata- } \\
\text { rata }\end{array}$ & 2 & 2,3 & 2,6 & 3 & 3 & 3,6 & 3,6 \\
\hline
\end{tabular}

Berdasarkan tabel 3 di atas dapat diuraikan bahwa penilaian perawatan rambut rontok menggunakan pemanfaatan lidah mertua sebagai hair tonic dengan frekuensi pemakaian 1 kali 3 hari yaitu kerontokan rambut. Rata-rata menunjukkan skor 2 pada saat pree test, pada perlakuan 1 skor rata-rata 2,3, perlakuan 2 skor rata-rata 2,6, perlakuan 3 dan perlakuan 4 skor rata-rata 3, dan perlakuan 5 dan perlakuan 6 skor rata-rata 3,6. Hasil penelitian ini menunjukkan bahwa tingkat keberhasilan perawatan rambut menggunakan lidah mertua sebagai hair tonic menunjukkan keberhasilan dari saat pretest sampai perlakuan ke 6. Hasil penelitian ini menunjukkan keberhasilan dari saat pretest hingga 6 kali perlakuan perawatan.

\section{B. Uji Persyaratan Analisis \\ 1. Uji Normalitas}

Tabel 4 Uji Normalitas Pada Ketiga Kelompok

One-Sample Kolmogorov-Smirnov Test

\begin{tabular}{|c|c|c|}
\hline & & Posttes \\
\hline \multicolumn{2}{|c|}{$\mathrm{N}$} & 9 \\
\hline \multirow[t]{2}{*}{ Normal Parameters $^{\mathrm{a}}$} & Mean & 3.0444 \\
\hline & Std. Deviation & .32059 \\
\hline \multirow{3}{*}{$\begin{array}{c}\text { Most Extreme } \\
\text { Differences }\end{array}$} & Absolute & .242 \\
\hline & Positive & .222 \\
\hline & Negative & -.242 \\
\hline \multicolumn{2}{|c|}{ Kolmogorov-Smirnov Z } & .725 \\
\hline \multicolumn{2}{|c|}{ Asymp. Sig. (2-tailed) } & .669 \\
\hline & $\mathrm{rmo}$ & \\
\hline
\end{tabular}


Berdasarkan uraian di atas didapatkan semua uji mempunyai nilai $\mathrm{p}>0,05$, hal ini menunjukkan data berdistribusi normal.

\section{Uji Homogenitas}

Tabel 5 Uji Homogenitas Pada Ketiga Kelompok

\section{Test of Homogeneity of Variances}

Posttes

\begin{tabular}{|c|c|c|c|}
\hline Levene Statistic & df1 & $\mathrm{df} 2$ & Sig. \\
\hline 3.185 & 2 & 6 & .114 \\
\hline
\end{tabular}

Berdasarkan uraian di atas didapatkan semua uji mempunyai nilai $\mathrm{p}>0,05$, hal ini menunjukkan data homogen.

\section{Pengujian Hipotesis}

Tabel 6. Hasil Analisis Perbandingan (ANOVA)

\begin{tabular}{|c|r|r|r|r|r|}
\hline \multicolumn{7}{|c|}{ ANOVA } \\
\hline Posttes & $\begin{array}{c}\text { Sum of } \\
\text { Squares }\end{array}$ & df & $\begin{array}{c}\text { Mean } \\
\text { Square }\end{array}$ & F & Sig. \\
\hline & .542 & 2 & .271 & 5.810 & .039 \\
\hline $\begin{array}{c}\text { Between } \\
\text { Groups }\end{array}$ & .280 & 6 & .047 & & \\
\hline $\begin{array}{c}\text { Within } \\
\text { Groups }\end{array}$ & .822 & 8 & & & \\
\hline Total & & & & \\
\hline
\end{tabular}

Berdasarkan tabel di atas dapat diperhatikan bahwa nilai Fhitung adalah (5.810) sedangkan nilai Ftabel untuk ketentuan df 8 pada taraf signifikan 5\% adalah sebesar (1.860). Dengan demikian harga Fhitung > Ftabel (5.810 $>$ 1.860), maka Ho ditolak, artinya terdapat perbedaan pengaruh yang signifikan terhadap pemanfaatan hair tonic lidah mertua terhadap perawatan rambut rontok. Karena dinyatakan ketiga kelompok data berbeda secara signifikan maka dilakukan uji lanjut untuk menganalisis kelompok perlakuan mana yang berbeda, analisis dilakukan dengan cara uji Duncan, berikut analisis Uji lanjutan:

\section{Tabel 9. Hasil Analisis Uji Lanjut (Duncan) Indikator Jumlah RambutYang Terlepas DariAkarnya Setiap Hari}

\section{Skor}

Duncan

\begin{tabular}{|c|c|c|c|}
\hline \multirow[b]{2}{*}{ Kelompok } & \multirow[b]{2}{*}{$\mathrm{N}$} & \multicolumn{2}{|c|}{ Subset for alpha $=0.05$} \\
\hline & & 1 & 2 \\
\hline Kontrol (X1) & 3 & 2.7333 & \\
\hline 1 x 3 hari(X3) & 3 & 3.0667 & 3.0667 \\
\hline $1 \times 2$ hari (X2) & 3 & & 3.3333 \\
\hline Sig. & & .108 & .181 \\
\hline
\end{tabular}

Berdasarkan analisis Uji Duncan di atas maka dapat dijelaskan bahwa kelompok kontrol $\left(\mathrm{X}_{1}\right)$ dengan rata-rata (2.73) berbeda secara signifikan dengan kelompok perlakuan dengan frekuensi 1 x 2 hari $\left(\mathrm{X}_{2}\right)$ dengan nilai rata-rata (3.33), yang tidak berbeda secara signifikan dengan kelompok perlakuan dengan frekuensi 1 x 3 hari $\left(\mathrm{X}_{3}\right)$ dengan skor rata-rata (3.07). Dengan demikian dinyatakan bahwa antara $X_{1}$ berbeda dengan $X_{2}$, tidak berbeda dengan $X_{3}$, sedangkan $X_{2}$ dan $X_{3}$ tidak berbeda secara signifikan (nyata).

\section{PENUTUP}

\section{Simpulan}

Berdasarkan hasil penelitian maka dapat disimpulkan sebagai berikut :

1. Perawatan rambut rontok tanpa penggunaan lidah mertua sebagai hair tonic pada kelompok kontrol (X1) tidak ada perubahan yang signifikan, dilihat dari hasil olahan data mulai dari perlakuan pertama (pretest) menunjukkan rata-rata 2,33 hingga perlakuan ke 6 (posttest) menunjukkan rata-rata 2,73.

2. Perawatan rambut rontok dengan menggunakan lidah mertua sebagai hair tonic pada kelompok eksperimen 1 (X2)dengan frekuensi 1 kali 2 hari terdapat perbedaan yang signifikan, dilihat dari olahan data mulai dari perlakuan pertama (pretest 2,00) hingga perlakuan 6 (posttest, 3,33), pada indikator kerontokan rambut terdapat perubahan yang signifikan. Dari hasil olahan data pada kelompok eksperimen 1 menunjukkan rata-rata pretest 2,00 menjadi posttest 3,33.

3. Perawatan rambut rontok dengan menggunakan lidah mertua sebagai hair tonic pada kelompok eksperimen 2(X3)dengan frekuensi 1 kali 3 hari terdapat perbedaan yang signifikan, dilihat dari olahan data 
mulai dari perlakuan pertama (pretest 2,00) hingga perlakuan 6 (posttest, 3,07), pada indikator kerontokan rambut terdapat perubahan yang signifikan. Dari hasil olahan data pada kelompok eksperimen 2 menunjukkan rata-rata pretest 2,00 menjadi posttest 3,07.

Terdapat perbedaanrata - rata ketiga kelompok, dengan hasil olahan uji duncan dapat dilihat perbandingan hasil rata-rata posttes pada setiap kelompok yaitu kelompok kontrol memiliki rata-rata postest $(2,73)$, kelompok eksperimen 1 memiliki rata-rata postest $(3,33)$, dan kelompok eksperimen 2 memiliki rata-rata postest $(3,07)$. Dari ketiga perbandingan rata-rata posttest ketiga kelompok dapat dilihat kelompok eksperimen 1 memiliki rata-rata posttest terbesar $(3,33)$ yang berarti penggunaan lidah mertua sebagai hair tonic lebih efisien digunakan dengan frekuensi pemakaian 1 kali 2 hari.

\section{Saran}

Setelah melakukan penelitian ini penelitian dapat memberikan saran bagi pihak terkait dalam bidang tata rias dan kecantikan, yaitu:

1. Kepada Prodi Pendidikan Tata Rias dan Kecantikan Fakultas Pariwisata dan Perhotelan,hasil penelitian ini dapat menjadi masukan dan referensi bahan perkuliahan pada mata kuliah perawatan rambut bahwa lidah mertua dapat dimanfaatkan sebagai hair tonic untuk perawatan rambut rontok yang berhubungan dengan perawatan rambut.

2. Bagi mahasiswa yang mengalami rambut rontok dapat menjadikan hasil penelitian ini sebagai bahan acuan dalam menghadapi permasalahan yang sama.

3. Bagi peneliti yang lainnya dapat menjadi bahan acuan dalam melakukan kajian yang sejenis terkait dengan tata kecantikan rambut.

4. Bagi peneliti selain syarat menyelesaikan pendidikan juga merupakan kesempatan untuk mencoba dan berlatih langsung melakukan eksperimen dalam menerapkan ilmu-ilmu yang diperoleh dari perkuliahan.

\section{DAFTAR PUSTAKA}

Annisa, S. U., Rusman. (2012). Cegah Diabetes dengan Rempeyek Lidah Mertua. Sekolah Menengah Analisis Kimia Bogor, Jawa Barat.

Nurjannah, maria krisnawati. 2014. "Pengaruh hair tonic lidah mertua (sansevieratrifasciataprain) dan seledri (apiumgraveolens linn)" health education http:// journal.unnes.ac.id/sju/index.php/bbhe ISSN 2252-7087.
Osawa, T.1994. Novel Natural Antioxidants For Utilization in Food and Biologycal System. In Postharvest Biochemistry of Plant Food Materials in The Tropics, Edisi Kesatu, Hlm. 241-251, Uritani, Garcia.

Rahmadewi, Menul Ayu Umborowati. 2012. Rambut Rontok Akibat Lingkungan dan Kosmetik (Environment and Cosmetic Induced Hair Loss) Jurnal Berkala Ilmu Kesehatan Kulit \& Kelamin Vol.24 No.1.

Rinawati, N.D. 2010. Daya Antibakteri Tumbuhan Majapahit (Crescentia Cejute Linn) Terhadap Bakteri Vibrio Alginolyticus. Surabaya: Institut Teknologi Sepiluh November.

Rostamailis. 2005. Perawatan Badan, Kulit dan Rambut. Jakarta: PT. Rineka Cipta.

Rostamailis \& Hayatunnufus.2008. Perawatan \& Penataan Rambut. Padang: UNP Press

Sani, Ruben. 2010. Perawatan Rambut Super Lengkap. Yogyakarta: Getar Hati.

Tranggono, R.I.1992. Kiat Apik Menjadi Sehat dan Cantik. Jakarta: PT. Gramedia.

Tranggono, R.I., dan Latifah, F., 2007, Pegangan Ilmu Pengetahuan Kosmetik, dalam Joshita Djajadisastra. Jakarta: Gramedia Pustaka Utama. 